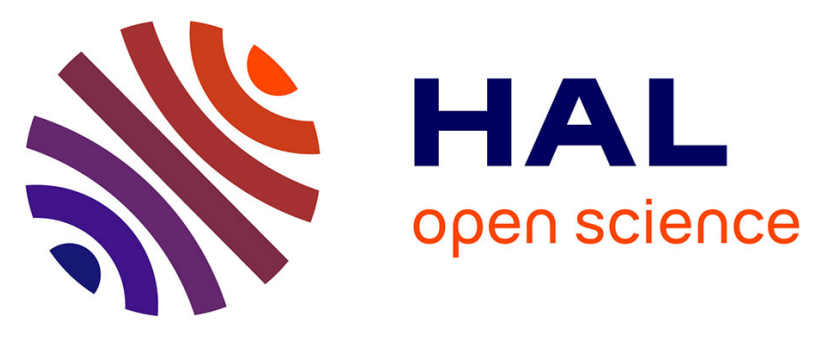

\title{
Effect of Eu3+ and Tb3+ ions concentration on the mechanical, structural, and photoluminescence properties of phosphate glass fibers
}

Rachid Mahiou, Oumaima Jamal Eddine, Damien Boyer, Mehdi El Bouchti, Aicha Boukhriss, Omar Cherkaoui, Hassan Hannache, Said Gmouh

\section{To cite this version:}

Rachid Mahiou, Oumaima Jamal Eddine, Damien Boyer, Mehdi El Bouchti, Aicha Boukhriss, et al.. Effect of Eu3+ and Tb3+ ions concentration on the mechanical, structural, and photoluminescence properties of phosphate glass fibers. Optical Materials, 2021, 122, pp.111664. 10.1016/j.optmat.2021.111664 . hal-03403653

\section{HAL Id: hal-03403653 https://hal.science/hal-03403653}

Submitted on 27 Oct 2021

HAL is a multi-disciplinary open access archive for the deposit and dissemination of scientific research documents, whether they are published or not. The documents may come from teaching and research institutions in France or abroad, or from public or private research centers.
L'archive ouverte pluridisciplinaire HAL, est destinée au dépôt et à la diffusion de documents scientifiques de niveau recherche, publiés ou non, émanant des établissements d'enseignement et de recherche français ou étrangers, des laboratoires publics ou privés. 
Research Article

\title{
Effect of $\mathrm{Eu}^{3+}$ and $\mathrm{Tb}^{3+}$ ions concentration on the mechanical, structural, and photoluminescence properties of phosphate glass fibers
}

\author{
Oumaima Jamal Eddine $^{\mathrm{a}}$, Damien Boyer ${ }^{\mathrm{b}}$, Mehdi El Bouchti ${ }^{\mathrm{c}}$, Aicha Boukhriss ${ }^{\mathrm{c}}$, \\ Omar Cherkaoui ${ }^{\mathrm{c}}$, Rachid Mahiou ${ }^{\mathrm{b}}$, Hassan Hannache ${ }^{\mathrm{a}, \mathrm{d}}$, Said Gmouh ${ }^{\mathrm{a}, *}$ \\ ${ }^{a}$ Hassan II University of Casablanca, Faculty of Sciences Ben M'scik, Chemistry Department, Laboratory LIMAT, Avenue Driss El Harti, BP 7955, Casablanca, Morocco \\ ${ }^{\mathrm{b}}$ Université Clermont Auvergne, Clermont Auvergne INP, CNRS, ICCF, F-63000, Clermont-Ferrand, France \\ ${ }^{\mathrm{c}}$ Higher School of Textile and Clothing Industries, Laboratory REMTEX, $\mathrm{km}$ 8, Route d'El Jadida, BP 7731, Oulfa, Casablanca, Morocco \\ ${ }^{\mathrm{d}}$ Mohammed VI Polytechnic University, Materials Science and Nanoengineering Department, Lot 660, Hay Moulay Rachid, Benguerir, Morocco
}

\section{A R T I C L E I N F O}

\section{Keywords:}

Phosphate glass fibers

$\mathrm{Eu}^{3+}$

$\mathrm{Tb}^{3+}$

Mechanical properties

Photoluminescence

\begin{abstract}
A B S T R A C T
Two series of phosphate glasses belonging to the (65-x) $\mathrm{P}_{2} \mathrm{O}_{5}-35 \mathrm{CaO}-\mathrm{xRE}_{2} \mathrm{O}_{3}$ system $(\mathrm{RE}=\mathrm{Eu}$ or $\mathrm{Tb} ; 0 \leq \mathrm{x} \leq 6$ mol\%) were prepared by the melt-quenching technique. All compositions were successfully drawn as continuous monofilaments fibers. The effect of $\mathrm{Eu}^{3+}$ and $\mathrm{Tb}^{3+}$ ions concentration on their mechanical, structural, and photoluminescence properties was investigated. The results revealed that the highest tensile strength was 1031 $\pm 34 \mathrm{MPa}$ for fibers doped with $6 \mathrm{~mol} \%$ of $\mathrm{Eu}_{2} \mathrm{O}_{3}$ and $1014 \pm 65 \mathrm{MPa}$ for fibers doped with $6 \mathrm{~mol} \%$ of $\mathrm{Tb}_{2} \mathrm{O}_{3}$. The addition of $\mathrm{RE}_{2} \mathrm{O}_{3}$ showed an increase in density and $\mathrm{Tg}$. A structural investigation was carried out using FTIR spectroscopy. The photoluminescence properties in terms of excitation and emission spectra were investigated in detail. The most intense emission band at $611 \mathrm{~nm}$ corresponds to the ${ }^{5} \mathrm{D}_{0} \rightarrow{ }^{7} \mathrm{~F}_{2}$ transition of Eu ${ }^{3+}$ ions under 392 $\mathrm{nm}$ excitation was observed for fibers doped with $6 \mathrm{~mol} \%$ of $\mathrm{Eu}_{2} \mathrm{O}_{3}$. The most intense emission band at $543 \mathrm{~nm}$ corresponds to the ${ }^{5} \mathrm{D}_{4} \rightarrow{ }^{7} \mathrm{~F}_{5}$ transition of $\mathrm{Tb}^{3+}$ ions under $374 \mathrm{~nm}$ excitation was observed for fibers doped with $6 \mathrm{~mol} \%$ of $\mathrm{Tb}_{2} \mathrm{O}_{3}$. These two compositions exhibited the highest absolute quantum yield, reaching $20.25 \%$ and $4.81 \%$, respectively.
\end{abstract}

\section{Introduction}

Phosphate glasses (PGs) are easy to produce and have great advantages due to their special properties that include high UV transparency, low infrared transparency, low melting temperature point, high thermal expansion, low dispersion, and regarded as better hosts for lanthanide ions $\left(\mathrm{Ln}^{3+}\right)$ [1-3]. It is well known that the luminescence properties of rare-earth ions (RE ions) result from their electronic structure [Xe] $4 f^{n} 5 d^{2} 6 s^{1}$. When these ions are inserted into a glassy network, the most stable and predominant oxidation state is trivalent and the $5 \mathrm{~d}$ and $6 \mathrm{~s}$ electronic layers are empty [4]. Among these different ions, $\mathrm{Eu}^{3+}([\mathrm{Xe}]$ $\left.4 f^{6}\right)$ and $\mathrm{Tb}^{3+}\left([\mathrm{Xe}] 4 \mathrm{f}^{8}\right)$ ions have been widely used as fluorescence-generating ions for the development of many luminescent materials, including PGs and phosphate glass fibers (PGFs) [5-7].

Generally, PGs doped with RE ions are well known for their high optical quality, as well as their higher doping concentration in comparison with that observed in silicate and borate glasses. In particular, PGs doped with $\mathrm{Eu}^{3+}$ and $\mathrm{Tb}^{3+}$ have been widely used in various optical devices such as optical fibers, amplifiers and lasers [7-9]. Their luminescence spectra are composed of many narrow lines as a consequence of $4 \mathrm{f}-4 \mathrm{f}$ transitions which are slightly sensitive to the environment of the $\mathrm{RE}^{3+}$ ion due to the shielding effect of $4 \mathrm{f}^{6}$ electrons by $5 \mathrm{~s}$ and $5 p$ electrons in outer shells in the $\operatorname{RE}^{3+}[4,10,11]$. They also present a sharp and bright red (at around 600-620 nm) and green (at around 545 $\mathrm{nm}$ ) emission, respectively, which are hypersensitive to the $\mathrm{RE}^{3+}$ ion surroundings than normal $\mathrm{f}-\mathrm{f}$ transitions $[12,13]$.

In the past several decades, the optical properties and the mechanisms of various vitreous systems based on calcium phosphate $\mathrm{P}_{2} \mathrm{O}_{5}-\mathrm{CaO}$ doped with europium or terbium ions have been studied [14-19]. Attention has been drawn to understand the basic theoretical models and experimental studies of the energy level structure, decay times of the excited states, energy transfer mechanisms, site symmetry

\footnotetext{
* Corresponding author.

E-mail addresses: jamaleddine.oumaima@gmail.com (O. Jamal Eddine), damien.boyer@sigma-clermont.fr (D. Boyer), melbouchti@gmail.com (M. El Bouchti),

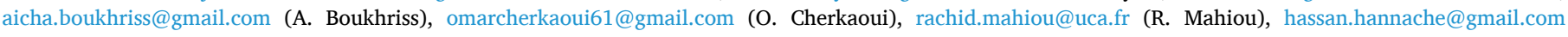
(H. Hannache), s.gmouh1@gmail.com (S. Gmouh).
} 
determination, anomalous spectral properties, etc. However, to the best of our knowledge, studies of the effect of the percentage of $\mathrm{Eu}_{2} \mathrm{O}_{3}$ and $\mathrm{Tb}_{2} \mathrm{O}_{3}$ in the $\mathrm{P}_{2} \mathrm{O}_{5}-\mathrm{CaO}$ system on the structural and photoluminescence properties were not mentioned. In this regard, new PGs with compositions based on the $\mathrm{P}_{2} \mathrm{O}_{5}-\mathrm{CaO}-\mathrm{RE}_{2} \mathrm{O}_{3}$ system with $\mathrm{RE}=\mathrm{Eu}$ or $\mathrm{Tb}$ were prepared. On the other hand, the elaborated PGs were stretched into PGFs to demonstrate the possibility of functionalizing small diameter non-woven PGFs (average diameter of a few micrometers) by doping with RE ions. It is expected that the introduction of the europium or terbium oxides into the studied glassy systems may affect the mechanical, structural and photoluminescence properties of the investigated fibers.

\section{Experiment}

Two series of PGs doped with RE ions were prepared by the conventional melt-quenching technique. Series 1 presents PGs doped with europium ions (see Table 1 ) and belongs to the (65- $x$ ) $\mathrm{P}_{2} \mathrm{O}_{5}-35 \mathrm{CaO}-\mathrm{xEu}_{2} \mathrm{O}_{3}$ system while series 2 presents PGs doped with terbium ions (see Table 2) and belongs to the (65- $x$ ) $\mathrm{P}_{2} \mathrm{O}_{5}-35 \mathrm{CaO}-\mathrm{xTb}_{2} \mathrm{O}_{3}$ system, where $0 \leq \mathrm{x} \leq 6 \mathrm{~mol} \%$. The binary glass $\left(\mathrm{OJ}_{0}\right)$ without the addition of $\mathrm{RE}_{2} \mathrm{O}_{3}$ was prepared in order to estimate the influence of the latter on the properties of PGFs. The starting materials used are high-purity commercial reagents (Sigma-Aldrich): tricalcium phosphate $\mathrm{Ca}_{3}\left(\mathrm{PO}_{4}\right)_{3}(\geq 96.0 \%)$, europium oxide $\mathrm{Eu}_{2} \mathrm{O}_{3}$ ( $\geq 99.99 \%$ ), and terbium oxide $\mathrm{Tb}_{2} \mathrm{O}_{3}(\geq 99.99 \%)$. Afterward, the materials were mixed homogeneously and then heated to $600^{\circ} \mathrm{C}$ for $2 \mathrm{~h}$ in a platinum crucible. Subsequently, it was melted at $900{ }^{\circ} \mathrm{C}$ for $1 \mathrm{~h}$ and cooled in air.

All PGs samples were successfully transformed into continuous monofilaments fibers by a melt-draw spinning process. The spinning process reported here was carried out with the steps and precautions described in detail in our previous papers [20,21]. In this study, the winding speed was set at $538 \mathrm{rpm}$ and the optimal spinning temperatures are $750{ }^{\circ} \mathrm{C}$ (temperature at the top) and $550{ }^{\circ} \mathrm{C}$ (temperature at the bottom). The average diameter measured for several PGFs was $22.1 \pm$ $0.8 \mu \mathrm{m}$. No correlation was noticed with the composition and diameters values obtained. All PGFs samples are colorless and transparent under daylight. Fig. 1 shows photographs of some PGs and PGFs samples of the compositions: $\mathrm{OJ}_{0}$ (under daylight), and $\mathrm{OJ}_{7}, \mathrm{OJ}_{11}$ and $\mathrm{OJ}_{14}$ (under UV-A light illumination; $\lambda_{\text {excitation }}=365 \mathrm{~nm}$ ). Under the UV-A lamp, $\mathrm{Eu}^{3+}$-doped samples show a strong red fluorescence, while $\mathrm{Tb}^{3+}$-doped samples show a bright green fluorescence, observed with the naked eye. However, under the same preparation conditions, the PGFs doped with more than $6 \mathrm{~mol} \%$ of $\mathrm{RE}_{2} \mathrm{O}_{3}$ showed low fluorescence under the UV-A lamp compared to the other PGFs compositions.

Scanning electron microscope (SEM) image of the $\mathrm{OJ}_{6}$ fiberglass sample was taken with ZEISS Supra 55VP scanning electron microscope. The mechanical properties of the PGFs were investigated by tensile tests using a tensile testing machine (model LUDWIC Mpk, made in Germany) [20,21], according to BS ISO 11566:1996 [22]. The values of the density ( $\rho$ ) were measured by immersing the samples of PGFs according to the

Table 1

Nominal composition (mol\%), calculated $(\mathrm{O} / \mathrm{P})$ ratio, density $(\rho)$, and molar volume $(\mathrm{Vm})$ of $\mathrm{Eu}^{3+}$-doped PGFs.

\begin{tabular}{lllllll}
\hline Series 1 & \multicolumn{3}{l}{ Compounds (in mol\%) } & $\mathrm{O} / \mathrm{P}$ & $\rho\left[\mathrm{g} \cdot \mathrm{cm}^{-3}\right]$ & $V_{m}\left[\mathrm{~cm}^{3} \cdot \mathrm{mol}^{-1}\right]$ \\
\cline { 2 - 4 } & $\mathrm{P}_{2} \mathrm{O}_{5}$ & $\mathrm{CaO}$ & $\mathrm{Eu}_{2} \mathrm{O}_{3}$ & & & \\
\hline $\mathrm{OJ}_{0}$ & 65 & 35 & 0 & 2.61 & 2.18 & 51.33 \\
$\mathrm{OJ}_{1}$ & 64.5 & 35 & 0.5 & 2.64 & 2.42 & 46.67 \\
$\mathrm{OJ}_{2}$ & 64 & 35 & 1 & 2.67 & 2.47 & 46.15 \\
$\mathrm{OJ}_{3}$ & 63 & 35 & 2 & 2.73 & 2.56 & 45.35 \\
$\mathrm{OJ}_{4}$ & 62 & 35 & 3 & 2.79 & 2.65 & 44.60 \\
$\mathrm{OJ}_{5}$ & 61 & 35 & 4 & 2.86 & 2.78 & 43.27 \\
$\mathrm{OJ}_{6}$ & 60 & 35 & 5 & 2.93 & 2.94 & 41.63 \\
$\mathrm{OJ}_{7}$ & 59 & 35 & 6 & 3.00 & 3.04 & 40.95 \\
\hline
\end{tabular}

Table 2

Nominal composition (mol\%), calculated $(\mathrm{O} / \mathrm{P})$ ratio, density $(\rho)$, and molar volume $(\mathrm{Vm})$ of $\mathrm{Tb}^{3+}$-doped PGFs.

\begin{tabular}{lllllll}
\hline \multirow{2}{*}{ Series 2 } & \multicolumn{3}{l}{ Compounds (in mol\%) } & $\mathrm{O} / \mathrm{P}$ & $\rho\left[\mathrm{g} \cdot \mathrm{cm}^{-3}\right]$ & $V_{m}\left[\mathrm{~cm}^{3} \cdot \mathrm{mol}^{-1}\right]$ \\
\cline { 2 - 4 } & $\mathrm{P}_{2} \mathrm{O}_{5}$ & $\mathrm{CaO}$ & $\mathrm{Tb}_{2} \mathrm{O}_{3}$ & & & \\
\hline $\mathrm{OJ}_{0}$ & 65 & 35 & 0 & 2.61 & 2.18 & 51.33 \\
$\mathrm{OJ}_{8}$ & 64.5 & 35 & 0.5 & 2.64 & 2.47 & 45.75 \\
$\mathrm{OJ}_{9}$ & 64 & 35 & 1 & 2.67 & 2.51 & 45.47 \\
$\mathrm{OJ}_{10}$ & 63 & 35 & 2 & 2.73 & 2.63 & 44.25 \\
$\mathrm{OJ}_{11}$ & 62 & 35 & 3 & 2.80 & 2.71 & 43.77 \\
$\mathrm{OJ}_{12}$ & 61 & 35 & 4 & 2.87 & 2.85 & 42.40 \\
$\mathrm{OJ}_{13}$ & 60 & 35 & 5 & 2.94 & 3.01 & 40.89 \\
$\mathrm{OJ}_{14}$ & 59 & 35 & 6 & 3.01 & 3.09 & 40.56 \\
\hline
\end{tabular}

Archimedes technique (BS 10119) [21]. Then, the molar volume values $\left(V_{m}\right)$ were calculated using the expression $V_{m}=M / \rho$, where $\mathrm{M}$ is the molecular weight of PGFs. Differential thermal analysis (DTA) was performed using a PerkinElmer DTA7 instrument under a flowing nitrogen atmosphere with a fixed heating rate of $10{ }^{\circ} \mathrm{C} / \mathrm{min}$ up to a maximum temperature of $1000{ }^{\circ} \mathrm{C}$. Errors in measurement are $\pm 2{ }^{\circ} \mathrm{C}$. The X-ray diffraction (XRD) measurements were carried out using a Siemens D501 diffractometer $\left(\lambda_{\mathrm{Cu}}=1.5406 \AA\right)$ in the range of $10-80^{\circ}$. The Fourier transform infrared (FTIR) spectra were recorded at room temperature within the wavenumber range $400-4000 \mathrm{~cm}^{-1}$ using a Thermo Electron spectrometer (Nicolet 5700-FTIR model). Photoluminescence (PL) spectra of doped PGFs samples were recorded using as excitation source a xenon lamp monochromatized through a TRIAX 180 Jobin-Yvon/Horiba and TRIAX 550 Jobin-Yvon/Horiba monochromator equipped with R928 Hamamatsu photomultiplier as a detector. For the $\mathrm{Eu}^{3+}$-doped PGFs samples $\left(\lambda_{\mathrm{ex}}=392 \mathrm{~nm}\right)$ and the $\mathrm{Tb}^{3+}$-doped PGFs samples $\left(\lambda_{\mathrm{ex}}=374 \mathrm{~nm}\right)$, the PL data were recorded in the range 400-750 $\mathrm{nm}$. Quantum yield (QY) efficiencies were measured using the Hamamatsu Photonics measurement system under the reference C9920-02G. The setup comprises a 150 W monochromatized Xe lamp, an integrating sphere (Spectralon Coating, $\varnothing=3.3$ in.), and a high sensitivity CCD spectrometer for detecting the whole spectral luminescence simultaneously. The absolute quantum yield $(\Phi a)$ in percent was calculated using the expression $\Phi a=\Phi i^{*} A b s^{*} 100 \%$, where $\Phi i$ is the internal quantum yield (the ratio between the emitted and the absorbed photons by the material upon external excitation) and $A b s$ is the Absorbance. The CIE (Commission Internationale de l'Éclairage, International Commission on Illumination) color coordinates $(\mathrm{x}, \mathrm{y})$ were measured in an integrating sphere with a diode array rapid analyzer system (GL Optic integrating sphere GLS 500). All luminescence experiments were performed at ambient air.

\section{Results and discussion}

\subsection{Morphology}

SEM analysis was used to observe the appearance of PGFs surface. Fig. 2 shows a SEM image at 800 times magnification of $\mathrm{OJ}_{6}$ sample belonging to the $60 \mathrm{P}_{2} \mathrm{O}_{5}-35 \mathrm{CaO}-5 \mathrm{Eu}_{2} \mathrm{O}_{3}$ system. As it can be seen from this figure, the $\mathrm{OJ}_{6}$ PGF appears smooth and homogeneous.

\subsection{Mechanical properties}

The results of the tensile tests on $\mathrm{OJ}_{0}, \mathrm{OJ}_{7}, \mathrm{OJ}_{11}$, and $\mathrm{OJ}_{14}$ samples are presented in Table 3. The values of tensile strength $(\sigma)$, Young's modulus $(E)$ and breaking strain $(\varepsilon)$ of the reference PGFs of $65 \mathrm{P}_{2} \mathrm{O}_{5}-35 \mathrm{CaO}$ system were $724 \pm 53 \mathrm{MPa}, 63 \pm 3 \mathrm{GPa}$, and $1.16 \pm$ $0.10 \%$, respectively. Slivka et al. [23] tested individual calcium PGFs of the $66 \mathrm{P}_{2} \mathrm{O}_{5}-23 \mathrm{CaO}-8 \mathrm{ZnO}-3 \mathrm{Fe}_{2} \mathrm{O}_{3}$ system with a diameter of $25.5 \mu \mathrm{m}$. They found that the values obtained of tensile strength, Young's modulus, and breaking strain were $513 \mathrm{MPa}, 43 \mathrm{GPa}$, and $1.3 \%$, respectively. The significant values of mechanical quantities found in 

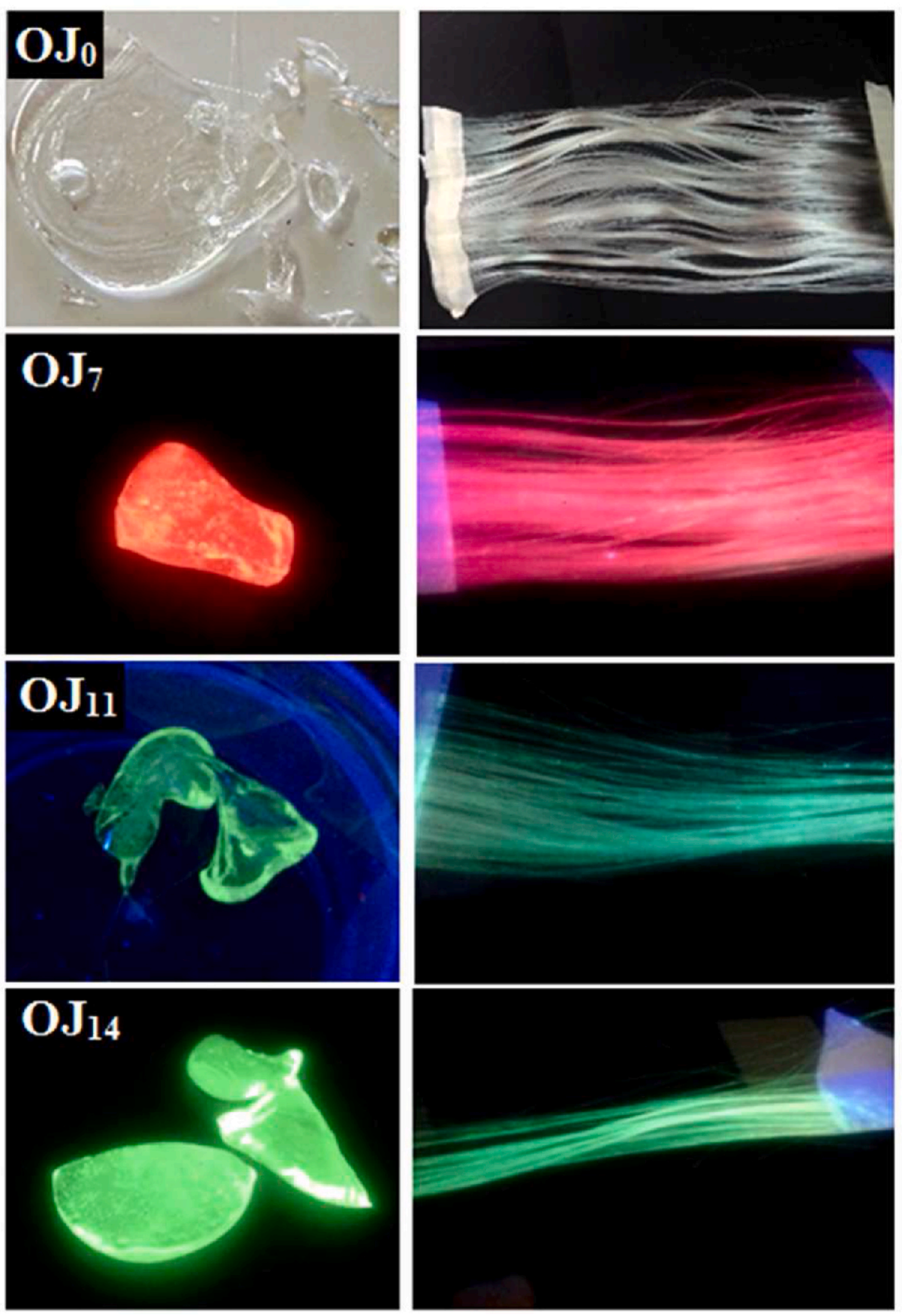

Fig. 1. Photographs of some PGs and PGFs; $\mathrm{OJ}_{0}$ (under daylight); $\mathrm{OJ}_{7}, \mathrm{OJ}_{11}$, and $\mathrm{OJ}_{14}$ (under UV-A light illumination; $\lambda_{\text {excitation }}=365 \mathrm{~nm}$ ).

our study can be explained by the dependence of the diameter on the tensile strength, and therefore on the breaking strain and Young's modulus. On the other hand, Ahmed et al. [24] tested individual calcium phosphate glass fibers of the $50 \mathrm{P}_{2} \mathrm{O}_{5}-50 \mathrm{CaO}$ system with a diameter of $20 \mu \mathrm{m}$. They found that the values obtained of tensile strength and Young's modulus were $475 \mathrm{MPa}$ and $44 \mathrm{GPa}$, respectively. These values are significantly lower than the values obtained in our study. This result can be explained by the excessive amount of $\mathrm{CaO}$ compared to $\mathrm{P}_{2} \mathrm{O}_{5}$, which influenced the mechanical properties of PGFs. Besides the effect of diameter and composition, a number of studies have shown that the spinning temperature plays a key role in the mechanical performance of fiberglass [25].

A significant increase in tensile strength, Young's modulus and thus breaking strain of fibers doped with $\mathrm{RE}_{2} \mathrm{O}_{3}$ compared to the reference
PGFs $\left(\mathrm{OJ}_{0}\right)$ is observed. The tensile strength values obtained were 1031 $\pm 34 \mathrm{MPa}$ for fibers doped with $6 \mathrm{~mol} \%$ of $\mathrm{Eu}_{2} \mathrm{O}_{3}$, and $861 \pm 71 \mathrm{MPa}$ and $1014 \pm 65 \mathrm{MPa}$ for fibers doped with 3 and $6 \mathrm{~mol} \%$ of $\mathrm{Tb}_{2} \mathrm{O}_{3}$, respectively. The Young's modulus values obtained for these 3 compositions were $80 \pm 6 \mathrm{GPa}, 73 \pm 4 \mathrm{GPa}$, and $79 \pm 7 \mathrm{GPa}$, respectively. At last, the values of breaking strain for these compositions are $1.29 \pm 0.23 \%, 1.18$ $\pm 0.11 \%$, and $1.28 \pm 0.20 \%$, respectively. The evolution of the mechanical properties of these fibers is due to the addition of $\mathrm{RE}_{2} \mathrm{O}_{3}$ with an appropriate amount in the PG composition. In addition, it has been suggested that fibers with a high modulus are more rigid.

\subsection{Density and molar volume}

Tables 1 and 2 present the $\mathrm{O} / \mathrm{P}$ ratio values and the average values of 


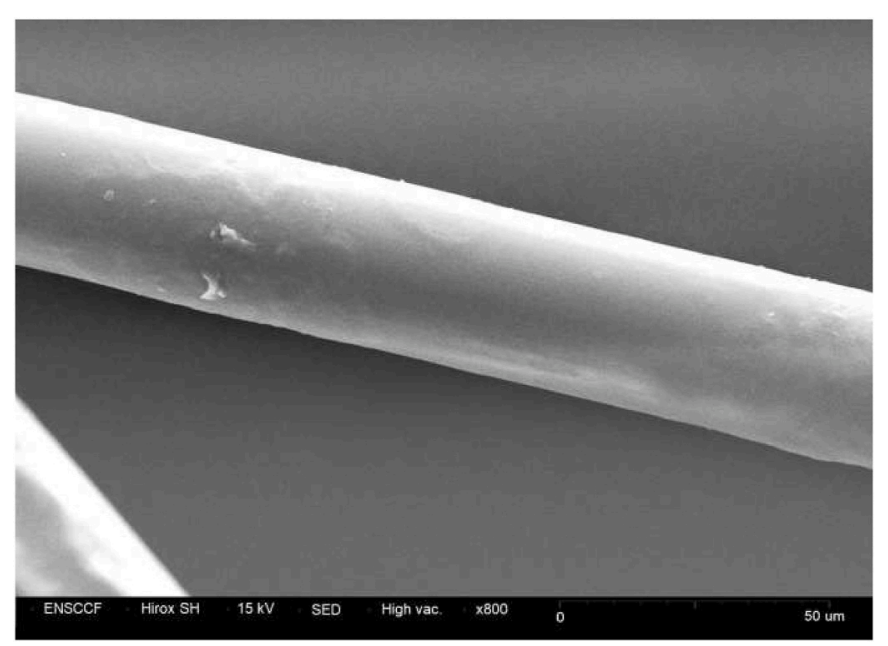

Fig. 2. SEM image of $\mathrm{OJ}_{6} \mathrm{Eu}^{3+}$-doped PGF.

density measurements and molar volume for all studied PGFs compositions. Fig. 3 shows the evolution of $\rho$ and $V_{m}$ as a function of each composition, from series 1 (see Fig. 3 (a)) and series 2 (see Fig. 3 (b)).

As shown in Tables 1 and $2, \mathrm{O} / \mathrm{P}=2.61$ for the reference PGFs $\left(\mathrm{OJ}_{0}\right)$, which means that the ultraphosphate groups $(5 / 2<\mathrm{O} / \mathrm{P}<3)$ of a long phosphate chain $\left(\mathrm{Q}^{3}\right)$ are dominant. These groups are highly concentrated in $\mathrm{P}_{2} \mathrm{O}_{5}$ of which the arrangement of $\mathrm{PO}_{4}$ tetrahedra forms a threedimensional network. When these fibers are doped with $6 \mathrm{~mol} \%$ of $\mathrm{Eu}_{2} \mathrm{O}_{3}$ or $\mathrm{Tb}_{2} \mathrm{O}_{3}$, the molar ratio $\mathrm{O} / \mathrm{P}$ becomes equal to 3 , which characterizes the metaphosphate groups rich in $\mathrm{PO}_{4}{ }^{3-}\left(\mathrm{Q}^{2}\right)$. These groups present a network formed of long chains and rings. Indeed, when the $\mathrm{Eu}_{2} \mathrm{O}_{3}$ or $\mathrm{Tb}_{2} \mathrm{O}_{3}$ content increases, it can be noted that the content of $\left(Q^{3}\right)$ structural entities decreases, and thus the content of $\left(Q^{2}\right)$ structural entities increases. Therefore, the bond length and bond angle of $\mathrm{P}-\mathrm{O}-\mathrm{P}$ in the glassy network structure also change [5].

Fig. 3 shows a linear increase in density as the $\mathrm{RE}_{2} \mathrm{O}_{3}$ content increases in the studied glassy systems. They increased from $2.18 \mathrm{~g} \mathrm{~cm}^{-3}$ for the $\mathrm{OJ}_{0}$ PGFs to $3.04 \mathrm{~g} \mathrm{~cm}^{-3}$ for the $\mathrm{OJ}_{7}$ PGFs and to $3.09 \mathrm{~g} \mathrm{~cm}^{-3}$ for the $\mathrm{OJ}_{14}$ PGFs. This increase can be explained by the fact that the molecular weights of $\mathrm{Eu}_{2} \mathrm{O}_{3}$ and $\mathrm{Tb}_{2} \mathrm{O}_{3}$ are greater than that of $\mathrm{P}_{2} \mathrm{O}_{5}$ and $\mathrm{CaO}$ and that the $\mathrm{Eu}^{3+}$ and $\mathrm{Tb}^{3+}$ ions have a strong aggregation. Furthermore, the molar volume of PGFs decreases with the $\mathrm{RE}_{2} \mathrm{O}_{3}$ content. These results indicate that the glassy network becomes more compact.

\subsection{Thermal analysis}

Fig. 4 shows the DTA curves of $\mathrm{OJ}_{0}, \mathrm{OJ}_{7}, \mathrm{OJ}_{11}$, and $\mathrm{OJ}_{14}$ PGFs. The values of glass transition temperature $(\mathrm{Tg})$ and melting temperature $(\mathrm{Tm})$ are collected in Table 3. The results show an increase in $\mathrm{Tg}$ and $\mathrm{Tm}$ values with the increase of $\mathrm{RE}_{2} \mathrm{O}_{3}$ content for both series. This increase is explained by the occupation of $\mathrm{Eu}^{3+}$ and $\mathrm{Tb}^{3+}$ ions of the interstitial sites of the glassy network. Therefore, the latter becomes more compact.

\subsection{Structural characterization}

The amorphous behavior of $\mathrm{Eu}^{3+}$ and $\mathrm{Tb}^{3+}$-doped PGFs was confirmed for all compositions by XRD analysis. Fig. 5 shows 4 examples of XRD patterns of PGFs samples $\left(\mathrm{OJ}_{0}, \mathrm{OJ}_{7}, \mathrm{OJ}_{11}\right.$, and $\left.\mathrm{OJ}_{14}\right)$. The broad hump characteristic in all XRD spectra indicates a non-crystalline structure in the glassy system.

Fig. 6 shows the infrared spectra of different samples from series 1 (Fig. 6a) and series 2 (Fig. 6b). As can be seen, the spectra of the fibers doped with $\mathrm{RE}_{2} \mathrm{O}_{3}$ show no significant changes. The FTIR spectrum of $\mathrm{OJ}_{0}$ fibers shows seven dominant bands observed at 1231, 1184, 1103, 996, 915, 741, and $514 \mathrm{~cm}^{-1}$ within the wavenumber range $400-4000$ $\mathrm{cm}^{-1}$. The infrared band assignments of the PGFs are listed in Table 4.

The vibrational bands around 1231 and $1184 \mathrm{~cm}^{-1}$ are attributed to asymmetric $\mathrm{v}_{\mathrm{as}}\left(\mathrm{PO}_{2}\right)$ and symmetric $\mathrm{v}_{\mathrm{s}}\left(\mathrm{PO}_{2}\right)$ stretching, respectively [1, $26,27]$. In this case, the two non-bridging oxygen (NBO) atoms easily connect to a phosphorus atom in the chain metaphosphate $\left(Q^{2}\right)$. The absorption bands shown at 1103 and $996 \mathrm{~cm}^{-1}$ correspond to the asymmetric $\mathrm{v}_{\text {as }}\left(\mathrm{PO}_{3}\right)$ and symmetric $\mathrm{v}_{\mathrm{s}}\left(\mathrm{PO}_{3}\right)$ stretching vibrations due to $\mathrm{PO}_{4}$ tetrahedra containing 2 and $3 \mathrm{NBO}$ atoms, respectively [1,28,29].
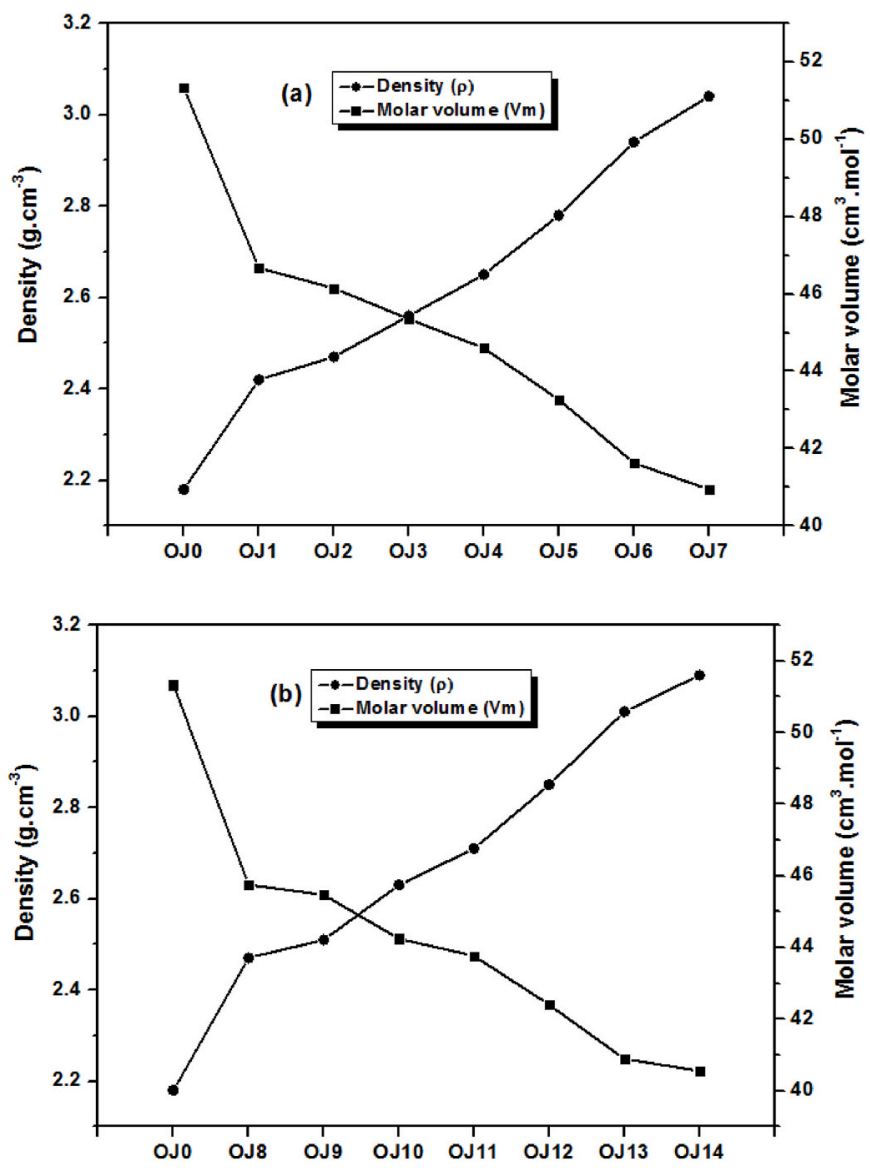

Fig. 3. Evolution of density $(\rho)$ and molar volume $\left(V_{m}\right)$ of (a) Eu ${ }^{3+}$-doped PGFs compositions and (b) $\mathrm{Tb}^{3+}$-doped PGFs compositions.

Table 3

Results of tensile tests and DTA analysis of PGFs samples.

\begin{tabular}{|c|c|c|c|c|c|c|}
\hline \multirow[t]{2}{*}{ PGFs code } & \multirow[t]{2}{*}{ Glass system } & \multirow{2}{*}{$\frac{\text { Tensile strength }}{\sigma(\mathrm{MPa})}$} & \multirow{2}{*}{$\frac{\text { Young's modulus }}{E(\mathrm{GPa})}$} & \multirow{2}{*}{$\frac{\text { Breaking strain }}{\varepsilon(\%)}$} & \multirow{2}{*}{$\frac{\text { Glass transition temperature }}{\operatorname{Tg}\left({ }^{\circ} \mathrm{C}\right)}$} & \multirow{2}{*}{$\frac{\text { Melting temperature }}{\operatorname{Tm}\left({ }^{\circ} \mathrm{C}\right)}$} \\
\hline & & & & & & \\
\hline $\mathrm{OJ}_{0}$ & $65 \mathrm{P}_{2} \mathrm{O}_{5}-35 \mathrm{CaO}$ & $724 \pm 53$ & $63 \pm 3$ & $1.16 \pm 0.10$ & 370 & 769 \\
\hline $\mathrm{OJ}_{7}$ & $59 \mathrm{P}_{2} \mathrm{O}_{5}-35 \mathrm{CaO}-6 \mathrm{Eu}_{2} \mathrm{O}_{3}$ & $1031 \pm 34$ & $80 \pm 6$ & $1.29 \pm 0.23$ & 509 & 801 \\
\hline $\mathrm{OJ}_{11}$ & $62 \mathrm{P}_{2} \mathrm{O}_{5}-35 \mathrm{CaO}-3 \mathrm{~Tb}_{2} \mathrm{O}_{3}$ & $861 \pm 71$ & $73 \pm 4$ & $1.18 \pm 0.11$ & 445 & 811 \\
\hline $\mathrm{OJ}_{14}$ & $59 \mathrm{P}_{2} \mathrm{O}_{5}-35 \mathrm{CaO}-6 \mathrm{~Tb}_{2} \mathrm{O}_{3}$ & $1014 \pm 65$ & $79 \pm 7$ & $1.28 \pm 0.20$ & 513 & 833 \\
\hline
\end{tabular}




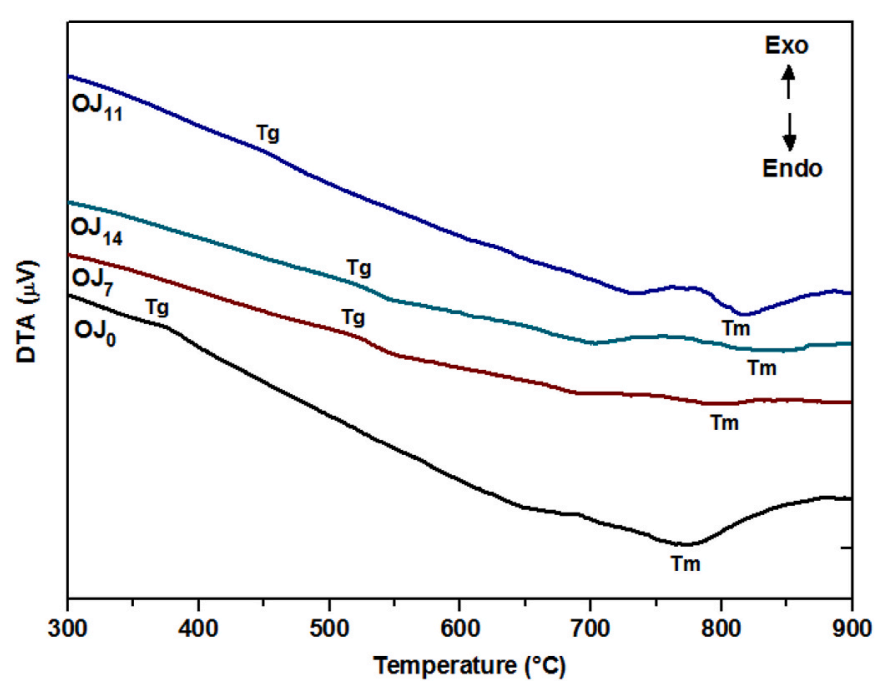

Fig. 4. DTA curves of PGFs samples at a heating rate of $10{ }^{\circ} \mathrm{C} / \mathrm{min}$ under nitrogen atmosphere.

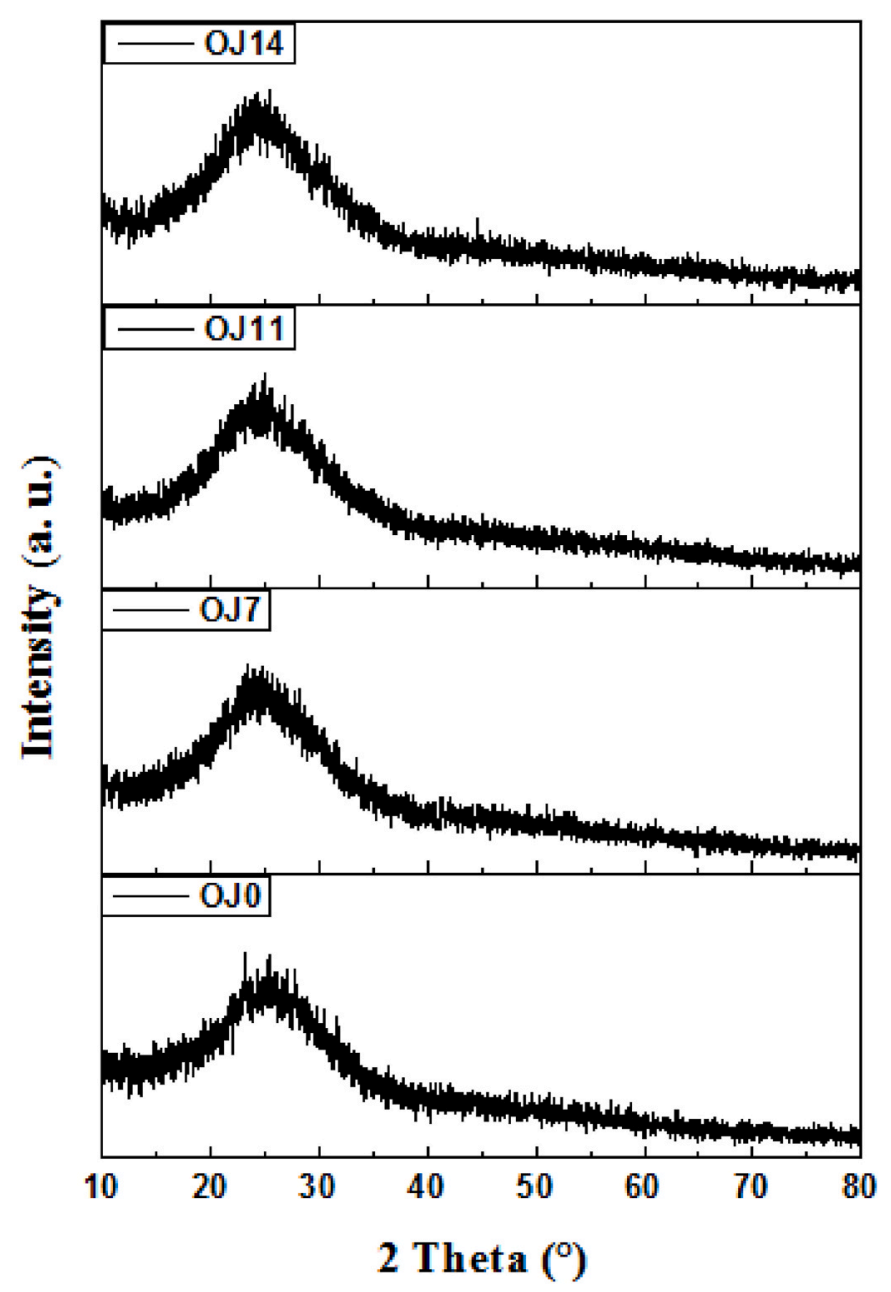

Fig. 5. X-ray diffraction patterns of PGFs samples.

These two bands are characteristic of the chain end groups $\left(Q^{1}\right)$.

The vibrational bands centered at 915 and $741 \mathrm{~cm}^{-1}$ are attributed to the asymmetric $\mathrm{v}_{\mathrm{as}}(\mathrm{P}-\mathrm{O}-\mathrm{P})$ and symmetric $\mathrm{v}_{\mathrm{s}}(\mathrm{P}-\mathrm{O}-\mathrm{P})$ stretching vibrations, respectively, of the bridging oxygen (BO) atoms bonded to a phosphorus atom in a phosphate tetrahedron [5,30,31]. These two bands are characteristic of intermediate entities $\left(Q^{2}\right)$.

At last, the broadband around $541 \mathrm{~cm}^{-1}$ can be ascribed to the deformation mode $\delta\left(\mathrm{PO}_{4}\right)^{3-}$ of the isolated tetrahedra groups characteristic of phosphate units $\left(\mathrm{Q}^{0}\right)[20,32,33]$.

\subsection{Photoluminescence properties}

Fig. 7 shows the excitation spectra (PLE) recorded at room temperature for $\mathrm{Eu}^{3+}$-doped fibers (Fig. 7 (a)) and $\mathrm{Tb}^{3+}$-doped fibers (Fig. 7 (b)). The characteristic excitation transitions of $\mathrm{Eu}^{3+}$-doped PGFs are ${ }^{7} \mathrm{~F}_{0}$ $\rightarrow{ }^{5} \mathrm{H}_{3-7}(323 \mathrm{~nm}),{ }^{7} \mathrm{~F}_{0} \rightarrow{ }^{5} \mathrm{D}_{4}(364 \mathrm{~nm}),{ }^{7} \mathrm{~F}_{0} \rightarrow{ }^{5} \mathrm{G}_{3}(373 \mathrm{~nm}),{ }^{7} \mathrm{~F}_{0} \rightarrow{ }^{5} \mathrm{G}_{2}$ $(385 \mathrm{~nm}),{ }^{7} \mathrm{~F}_{0} \rightarrow{ }^{5} \mathrm{~L}_{6}(392 \mathrm{~nm}),{ }^{7} \mathrm{~F}_{0} \rightarrow{ }^{5} \mathrm{D}_{3}(415 \mathrm{~nm})$, and ${ }^{7} \mathrm{~F}_{0} \rightarrow{ }^{5} \mathrm{D}_{2}$ (486 $\mathrm{nm})$. The most significant excitation transitions characteristic of $\mathrm{Tb}^{3+}$. doped PGFs are ${ }^{7} \mathrm{~F}_{6} \rightarrow{ }^{5} \mathrm{H}_{6}(301 \mathrm{~nm}),{ }^{7} \mathrm{~F}_{6} \rightarrow{ }^{5} \mathrm{H}_{7}(318 \mathrm{~nm}),{ }^{7} \mathrm{~F}_{6} \rightarrow\left({ }^{5} \mathrm{G}_{2}\right.$, $\left.{ }^{5} \mathrm{~L}_{8}\right)(345$ and $349 \mathrm{~nm}),{ }^{7} \mathrm{~F}_{6} \rightarrow\left({ }^{5} \mathrm{G}_{4},{ }^{5} \mathrm{~L}_{9}\right)(351 \mathrm{~nm}),{ }^{7} \mathrm{~F}_{6} \rightarrow{ }^{5} \mathrm{G}_{5}(358 \mathrm{~nm})$, ${ }^{7} \mathrm{~F}_{6} \rightarrow{ }^{5} \mathrm{~L}_{10}(366 \mathrm{~nm}),{ }^{7} \mathrm{~F}_{6} \rightarrow\left({ }^{5} \mathrm{G}_{6},{ }^{5} \mathrm{D}_{3}\right)(374 \mathrm{~nm})$, and ${ }^{7} \mathrm{~F}_{6} \rightarrow{ }^{5} \mathrm{D}_{4}(384$ $\mathrm{nm}$ ). From the PLE spectra, the maximum excitation wavelengths obtained are $392 \mathrm{~nm}$ and $374 \mathrm{~nm}$ for $\mathrm{Eu}^{3+}$-doped fibers and $\mathrm{Tb}^{3+}$-doped fibers, respectively, which are therefore chosen to record the emission spectra (PL). Figs. 8 and 9 show the PL spectra recorded at room temperature for some $\mathrm{Eu}^{3+}$-doped and $\mathrm{Tb}^{3+}$-doped PGFs compositions, respectively, with different dopant concentrations. The inhomogeneous broadening of the lines in the excitation and emission spectra is due to differences in the local environments around the RE ions in the disordered glassy system that arise from variations in both the $\mathrm{RE}-\mathrm{O}$ distances and in the coordination numbers of these elements [16,34,35].

Excitation energy is transferred nonradiatively to the ${ }^{5} \mathrm{D}_{0}$ state due to the relatively small energy gaps between the ${ }^{5} \mathrm{D}_{1},{ }^{5} \mathrm{D}_{2}$, and ${ }^{5} \mathrm{D}_{3}$ states from which radiative transitions occur [36]. Therefore, all emission bands recorded under excitation at $392 \mathrm{~nm}$ are associated with ${ }^{5} \mathrm{D}_{0} \rightarrow$ ${ }^{7} \mathrm{~F}_{\mathrm{J}}(\mathrm{J}=0-4)$ transitions appearing in the range between 570 and 750 $\mathrm{nm}$. These intense bands belonging to the internal $4 \mathrm{f}-4 \mathrm{f}$ transitions of $\mathrm{Eu}^{3+}$ ions appear in each spectrum. The characteristic emission bands of $\mathrm{Eu}^{3+}$-doped PGFs located around 578, 592, 611, 651, and $697 \mathrm{~nm}$ correspond to the emission transitions ${ }^{5} \mathrm{D}_{0} \rightarrow{ }^{7} \mathrm{~F}_{0},{ }^{5} \mathrm{D}_{0} \rightarrow{ }^{7} \mathrm{~F}_{1},{ }^{5} \mathrm{D}_{0} \rightarrow{ }^{7} \mathrm{~F}_{2}$, ${ }^{5} \mathrm{D}_{0} \rightarrow{ }^{7} \mathrm{~F}_{3}$, and ${ }^{5} \mathrm{D}_{0} \rightarrow{ }^{7} \mathrm{~F}_{4}$, respectively.

In this study, we examine in detail the spectral distribution for each emission transition of $\mathrm{Eu}^{3+}$ ions in the (65-x) $\mathrm{P}_{2} \mathrm{O}_{5}-35 \mathrm{CaO}-\mathrm{xEu}$ system (with $\mathrm{x}=2,3,5$, and $6 \mathrm{~mol} \%$ ). Although the ${ }^{5} \mathrm{D}_{0} \rightarrow{ }^{7} \mathrm{~F}_{0}$ transition is often observed in emission spectra, it is strictly forbidden according to the standard Judd-Ofelt (JO) theory [12,37]. Previous studies indicate that the appearance of this transition can be attributed to J-mixing effects $[38,39]$ or the mixing of low charge-transfer states in the wave functions of the $4 \mathrm{f}^{6}$ configuration $[12,40]$. This very weak transition is identified as an electric dipole (ED). The ${ }^{5} \mathrm{D}_{0} \rightarrow{ }^{7} \mathrm{~F}_{1}$ transition is an allowed magnetic dipole (MD) and its intensity is generally independent of the local symmetry [41-43]. The most intense band with red emission at $611 \mathrm{~nm}$ corresponds to the ${ }^{5} \mathrm{D}_{0} \rightarrow{ }^{7} \mathrm{~F}_{2}$ transition is hypersensitive to the local symmetry of $\mathrm{Eu}^{3+}$ ions $[12,40]$. This transition has a purely (ED) character. The ${ }^{5} \mathrm{D}_{0} \rightarrow{ }^{7} \mathrm{~F}_{3}$ transition is weak because it is forbidden according to the standard (JO) theory [5]. This transition is identified as (ED) character and can only gain intensity by J-mixing [44]. At last, the ${ }^{5} \mathrm{D}_{0}$ $\rightarrow{ }^{7} \mathrm{~F}_{4}$ (ED) transition is allowed according to the selection rules [40]. In the studied $\mathrm{Eu}^{3+}$-doped PGFs systems, it is clearly seen that this transition has a lower integral intensity than the intensity of the ${ }^{5} \mathrm{D}_{0} \rightarrow{ }^{7} \mathrm{~F}_{2}$ transition and slightly more intense than the ${ }^{5} \mathrm{D}_{0} \rightarrow{ }^{7} \mathrm{~F}_{1}$ transition. This result is similar to several previously reported PG systems [29,45-49]. On the other hand, the intensities of the emission bands increase significantly with increasing $\mathrm{Eu}^{3+}$ ions concentration up to $6 \mathrm{~mol} \%$ of $\mathrm{Eu}_{2} \mathrm{O}_{3}$, while the peaks are at the same energy positions with a rather similar shape. Similar results were obtained for PGs doped with different concentrations of $\mathrm{Eu}^{3+}[36,50,51]$.

The characteristic PL bands of PGFs in the (65-x) $\mathrm{P}_{2} \mathrm{O}_{5}-35 \mathrm{CaO}-\mathrm{xTb}$ system (with $\mathrm{x}=3,5$, and $6 \mathrm{~mol} \%$ ) recorded under $374 \mathrm{~nm}$ excitation are attributed to $\mathrm{Tb}^{3+}$ ions. Several emission bands are observed from the ${ }^{5} \mathrm{D}_{3}$ and ${ }^{5} \mathrm{D}_{4}$ excited states in the blue and green/red spectral zone 

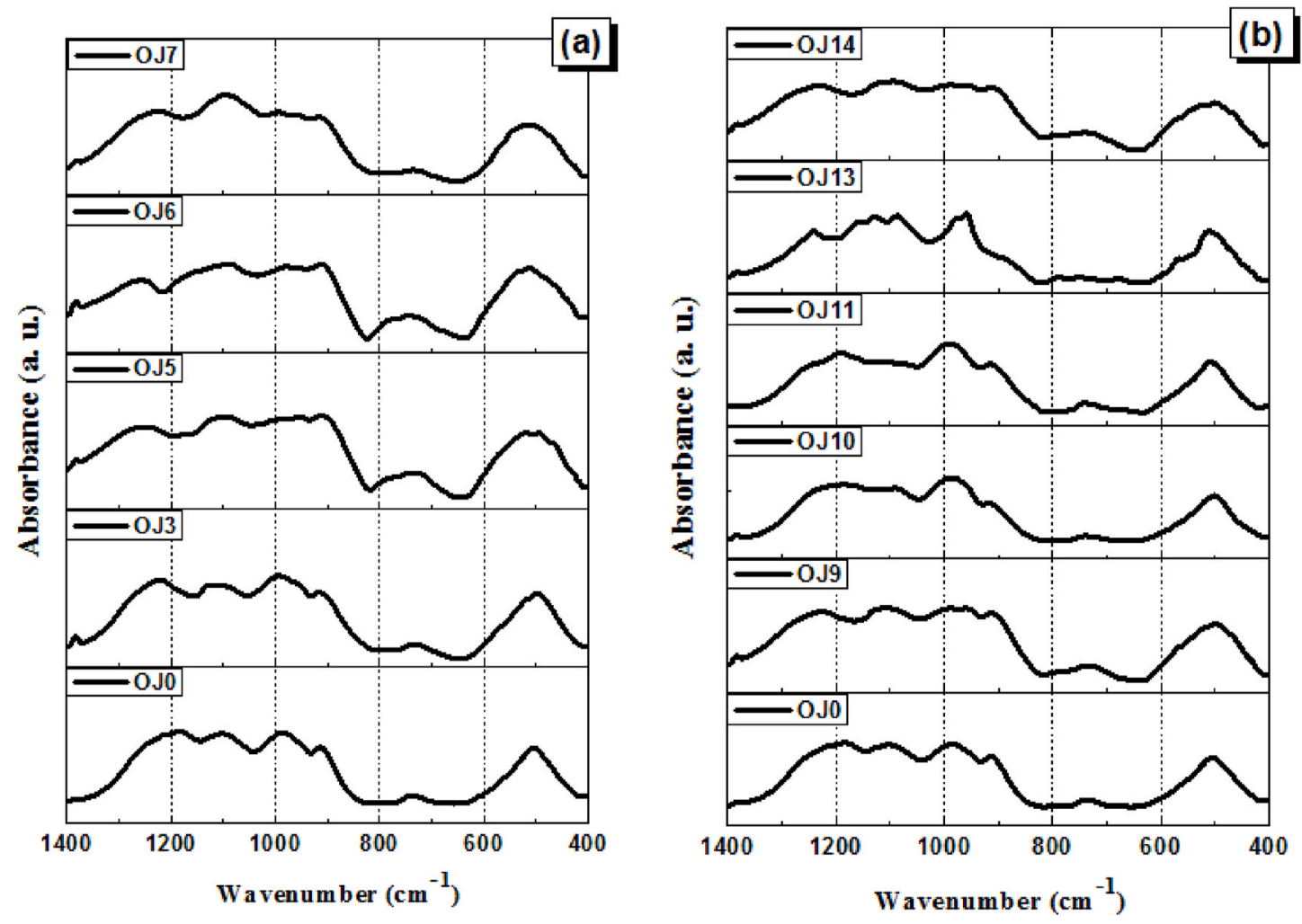

Fig. 6. FTIR spectra for the studied PGFs samples.

Table 4

Infrared band positions $\left(\mathrm{cm}^{-1}\right)$ and assignments of the PGFs samples.

\begin{tabular}{|c|c|}
\hline $\begin{array}{l}\text { Position } \\
\left(\mathrm{cm}^{-1}\right)\end{array}$ & Assignment \\
\hline$\sim 1231$ & $\begin{array}{l}\text { Asymmetric stretching vibration } \mathrm{v}_{\text {as }}\left(\mathrm{PO}_{2}\right)\left(\mathrm{NBO}^{*} \text { atoms; } \mathrm{Q}^{2}\right. \\
\text { species) }\end{array}$ \\
\hline$\sim 1184$ & Symmetric stretching vibration $\mathrm{v}_{\mathrm{s}}\left(\mathrm{PO}_{2}\right)\left(\mathrm{NBO} *\right.$ atoms; $\mathrm{Q}^{2}$ species$)$ \\
\hline$\sim 1103$ & $\begin{array}{l}\text { Asymmetric stretching vibration } \mathrm{v}_{\mathrm{as}}\left(\mathrm{PO}_{3}\right)\left(\mathrm{NBO}^{*} \text { atoms; } \mathrm{Q}^{1}\right. \\
\text { species) }\end{array}$ \\
\hline$\sim 996$ & Symmetric stretching vibration $\mathrm{v}_{\mathrm{s}}\left(\mathrm{PO}_{3}\right)\left(\mathrm{NBO} *\right.$ atoms; $\mathrm{Q}^{1}$ species) \\
\hline$\sim 915$ & $\begin{array}{l}\text { Asymmetric stretching vibration } \mathrm{v}_{\text {as }}(\mathrm{P}-\mathrm{O}-\mathrm{P})\left(\mathrm{BO} * \text { atoms; } \mathrm{Q}^{2}\right. \\
\text { species) }\end{array}$ \\
\hline$\sim 741$ & $\begin{array}{l}\text { Symmetric stretching vibration } \mathrm{v}_{\mathrm{s}}(\mathrm{P}-\mathrm{O}-\mathrm{P})\left(\mathrm{BO}^{*} \text { atoms; } \mathrm{Q}^{2}\right. \\
\text { species) }\end{array}$ \\
\hline$\sim 514$ & Bending vibration of $\delta\left(\mathrm{PO}_{4}\right)^{3-}$ groups \\
\hline
\end{tabular}

*BO: bridging oxygen; *NBO: non bridging oxygen.

[30,52]. The bands from the ${ }^{5} \mathrm{D}_{3}$ level are located around 412 and 418 , 433,460 , and 476 correspond to the emission transitions ${ }^{5} \mathrm{D}_{3} \rightarrow{ }^{7} \mathrm{~F}_{5},{ }^{5} \mathrm{D}_{3}$ $\rightarrow{ }^{7} \mathrm{~F}_{4},{ }^{5} \mathrm{D}_{3} \rightarrow{ }^{7} \mathrm{~F}_{3}$, and ${ }^{5} \mathrm{D}_{3} \rightarrow{ }^{7} \mathrm{~F}_{2}$, respectively. The bands from the ${ }^{5} \mathrm{D}_{4}$ level are located around 490, 543, 582, 619, 654, 668, and $679 \mathrm{~nm}$ correspond to the emission transitions ${ }^{5} \mathrm{D}_{4} \rightarrow{ }^{7} \mathrm{~F}_{6},{ }^{5} \mathrm{D}_{4} \rightarrow{ }^{7} \mathrm{~F}_{5},{ }^{5} \mathrm{D}_{4} \rightarrow{ }^{7} \mathrm{~F}_{4}$, ${ }^{5} \mathrm{D}_{4} \rightarrow{ }^{7} \mathrm{~F}_{3},{ }^{5} \mathrm{D}_{4} \rightarrow{ }^{7} \mathrm{~F}_{2},{ }^{5} \mathrm{D}_{4} \rightarrow{ }^{7} \mathrm{~F}_{1}$, and ${ }^{5} \mathrm{D}_{4} \rightarrow{ }^{7} \mathrm{~F}_{0}$, respectively. The most intense band with green emission is at $543 \mathrm{~nm}$, arises from the Laporte-forbidden ${ }^{5} \mathrm{D}_{4} \rightarrow{ }^{7} \mathrm{~F}_{5}$ (ED) transition [30,53]. This transition is hypersensitive to the $\mathrm{Tb}^{3+}$ environment [13]. Additionally, in the PL spectrum of PGFs doped with $6 \mathrm{~mol} \%$ of $\mathrm{Tb}_{2} \mathrm{O}_{3}$, this band is divided into two components due to the Stark division of energy levels [7]. The ${ }^{5} \mathrm{D}_{4} \rightarrow$ ${ }^{7} \mathrm{~F}_{6}$ transition obeys the (MD) transition selection rule of $\Delta \mathrm{J}= \pm 1[53$, 54]. Besides, this transition is almost independent of the environment [13]. The PL spectra show gradual increases in the intensity of the ${ }^{5} D_{4}$ level bands with the increment of $\mathrm{Tb}^{3+}$, while the peaks are at the same energy positions. The bands observed in the PL spectra of the ${ }^{5} \mathrm{D}_{3}$ level are due to a low rate of non-radiative processes from ${ }^{5} \mathrm{D}_{3}$ level to ${ }^{5} \mathrm{D}_{4}$ level [55]. These transitions are quenched at a high $\mathrm{Tb}^{3+}$ content when

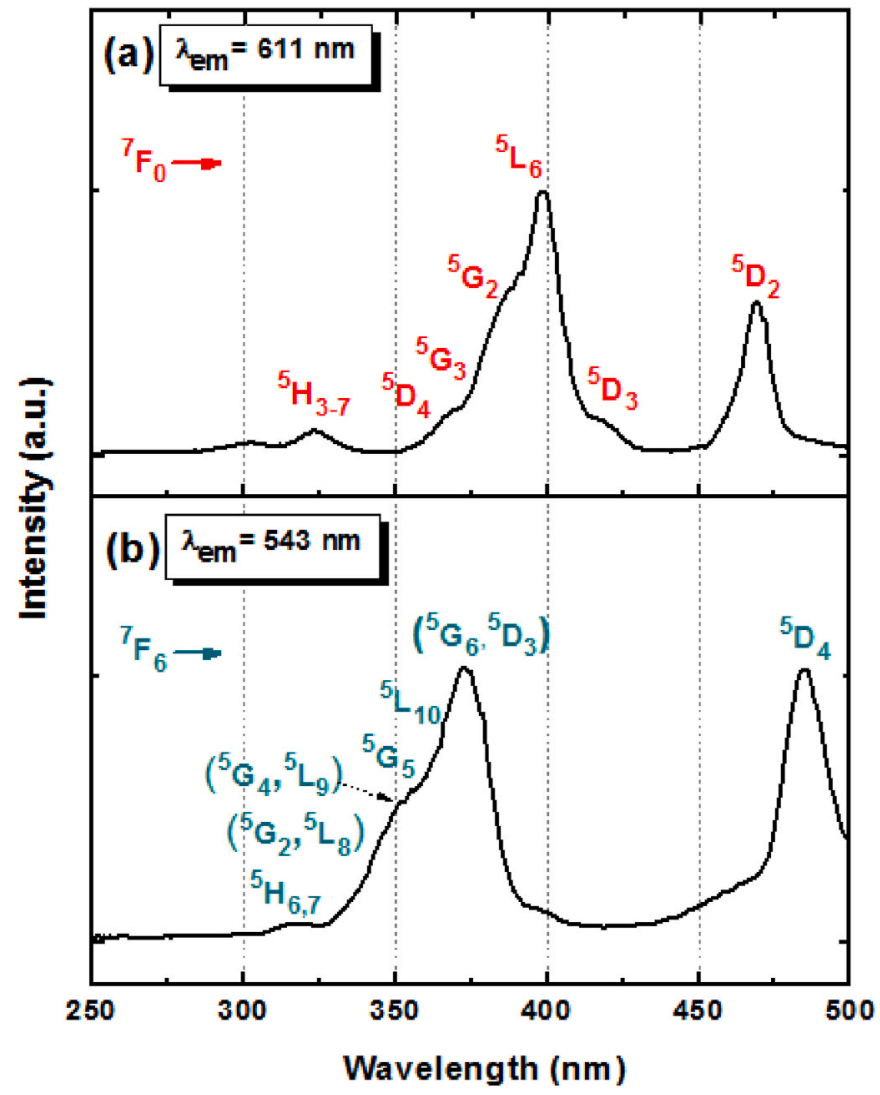

Fig. 7. Excitation spectra at $300 \mathrm{~K}$ of (a) $\mathrm{Eu}^{3+}$-doped PGFs for emission at 611 $\mathrm{nm}$ and (b) $\mathrm{Tb}^{3+}$-doped PGFs for emission at $543 \mathrm{~nm}$. 


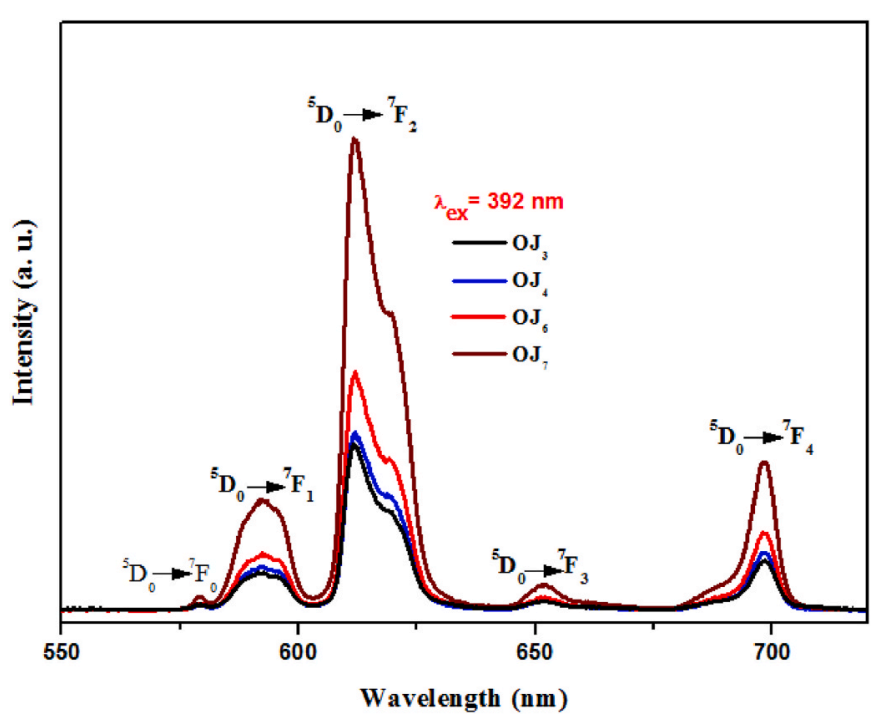

Fig. 8. Emission spectra of $\mathrm{Eu}^{3+}$-doped PGFs samples under $392 \mathrm{~nm}$ excitation at $300 \mathrm{~K}$.

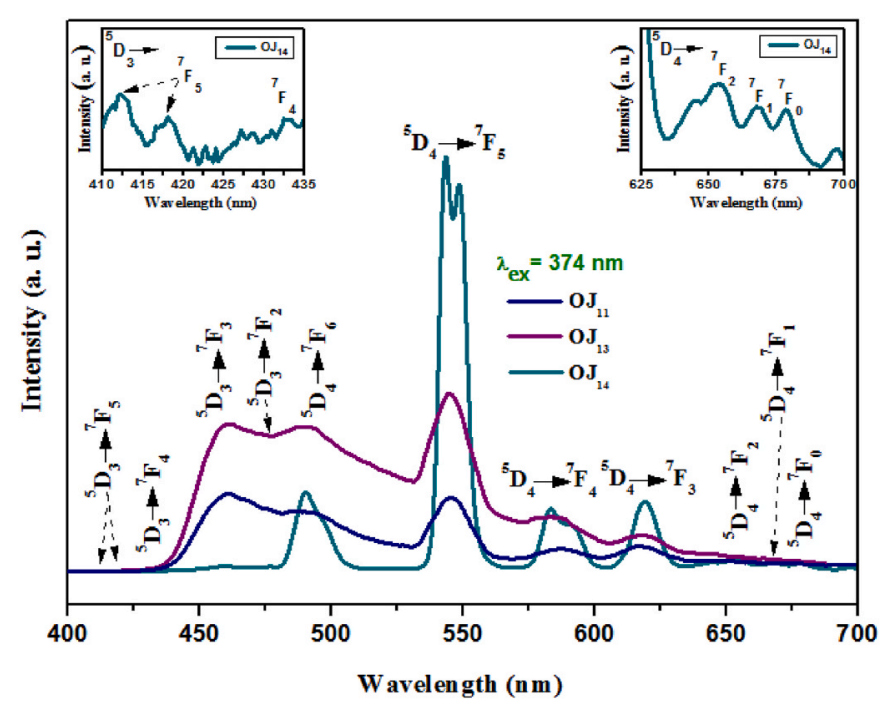

Fig. 9. Emission spectra of $\mathrm{Tb}^{3+}$-doped PGFs samples under $374 \mathrm{~nm}$ excitation at $300 \mathrm{~K}$.

the $\mathrm{Tb}_{2} \mathrm{O}_{3}$ content increased by $6 \mathrm{~mol} \%$. Previous works have indicated that the concentration of $\mathrm{Tb}^{3+}$ affects ${ }^{5} \mathrm{D}_{3}$ emission via the cross-relaxation (CR) process due to the reduction in distances [56-58]. Therefore, the band corresponding to the ${ }^{5} \mathrm{D}_{3} \rightarrow{ }^{7} \mathrm{~F}_{3}$ transition becomes too weak for the $\mathrm{OJ}_{14}$ sample.

The absolute quantum yield is described as the efficiency at which a material re-emits by fluorescence a certain number of photons absorbed at a given wavelength. Tables 5 and 6 show the calculated values of absolute quantum yield $(\Phi a)$ for all PGFs samples in both series. It can be seen that $\Phi a$ gradually increases with increasing $\mathrm{Eu}^{3+}$ or $\mathrm{Tb}^{3+}$ ions concentration. They vary from 3.61 to $20.25 \%$ for $\mathrm{Eu}^{3+}$-doped fibers upon excitation at $392 \mathrm{~nm}$, while for $\mathrm{Tb}^{3+}$-doped fibers the $\Phi a$ does not

Table 5

Calculated values of absolute quantum yields $(\Phi a)$ for $\mathrm{Eu}^{3+}$-doped PGFs samples.

\begin{tabular}{llllllll}
\hline PGFs & $\mathrm{OJ}_{1}$ & $\mathrm{OJ}_{2}$ & $\mathrm{OJ}_{3}$ & $\mathrm{OJ}_{4}$ & $\mathrm{OJ}_{5}$ & $\mathrm{OJ}_{6}$ & $\mathrm{OJ}_{7}$ \\
\hline$\Phi a(\%)$ & 3.61 & 8.84 & 12.47 & 16.75 & 17.32 & 18.31 & 20.25 \\
\hline
\end{tabular}

Table 6

Calculated values of absolute quantum yields ( $\Phi a$ ) for $\mathrm{Tb}^{3+}$-doped PGFs samples.

\begin{tabular}{llllllll}
\hline PGFs & $\mathrm{OJ}_{8}$ & $\mathrm{OJ}_{9}$ & $\mathrm{OJ}_{10}$ & $\mathrm{OJ}_{11}$ & $\mathrm{OJ}_{12}$ & $\mathrm{OJ}_{13}$ & $\mathrm{OJ}_{14}$ \\
\hline$\Phi a(\%)$ & 0.59 & 1.57 & 1.99 & 2.24 & 2.63 & 3.78 & 4.81 \\
\hline
\end{tabular}

exceed 5\% upon excitation at $374 \mathrm{~nm}$. On the other hand, the internal quantum yield ( $\Phi i$ ) varies by $62.80 \pm 10.10 \%$ for $\mathrm{OJ}_{7}$ PGFs and by 16.21 $\pm 4.85 \%$ for $\mathrm{OJ}_{14}$ PGFs, with $A b s$ values increasing with $\mathrm{RE}^{3+}$ ions concentration. To the best of our knowledge, there are no internal or absolute quantum yield data available for glassy systems comparable to those studied in this paper. Therefore, the results reported in this work provide original reference data to compare various $\mathrm{Eu}^{3+}$ and $\mathrm{Tb}^{3+}$ doped luminescent glass materials.

At last, the CIE color coordinates emitted by the two PGFs samples $\mathrm{OJ}_{7}$ and $\mathrm{OJ}_{14}$ are presented in the CIE 1931 chromaticity diagram in Fig. 10. $\mathrm{OJ}_{7}$ fibers give average color coordinates $(\mathrm{x}=0.648, \mathrm{y}=0.344)$ under $392 \mathrm{~nm}$ excitation and are found in the red light region. $\mathrm{OJ}_{14}$ fibers give average color coordinates $(x=0.295, y=0.477)$ under $374 \mathrm{~nm}$ excitation and are situated in the green light region.

\section{Conclusion}

In this study, fifteen phosphate glasses (PGs) formulations were developed by the melt-quenching technique and divided into two glass systems (65-x) $\mathrm{P}_{2} \mathrm{O}_{5}-35 \mathrm{CaO}-\mathrm{xEu}_{2} \mathrm{O}_{3}$ and (65-x) $\mathrm{P}_{2} \mathrm{O}_{5}-35 \mathrm{CaO}-\mathrm{xTb}_{2} \mathrm{O}_{3}$, with $0 \leq \mathrm{x} \leq 6 \mathrm{~mol} \%$. All compositions were successfully drawn as continuous monofilaments phosphate glass fibers (PGFs). The average diameter was $22.1 \pm 0.8 \mu \mathrm{m}$ with a fixed spinning speed. Morphological analysis performed by SEM showed that the elaborated fibers have a homogeneous and smooth surface. Their amorphous nature was confirmed by XRD and DTA. The mechanical properties of undoped PGFs were higher than those of PGFs in the literature. A significant increase in mechanical quantities was noticed with the addition of $6 \mathrm{~mol} \%$ of $\mathrm{RE}_{2} \mathrm{O}_{3}(\mathrm{RE}=\mathrm{Eu}$ or $\mathrm{Tb})$. The values of tensile strength, Young's modulus, and breaking strain were $1031 \pm 34 \mathrm{MPa}, 80 \pm 6 \mathrm{GPa}$, and $1.29 \pm 0.23 \%$, respectively, for fibers doped with $6 \mathrm{~mol} \%$ of $\mathrm{Eu}_{2} \mathrm{O}_{3}$ $\left(\mathrm{OJ}_{7}\right)$, and $1014 \pm 65 \mathrm{MPa}, 79 \pm 7 \mathrm{GPa}$, and $1.28 \pm 0.20 \%$, respectively,

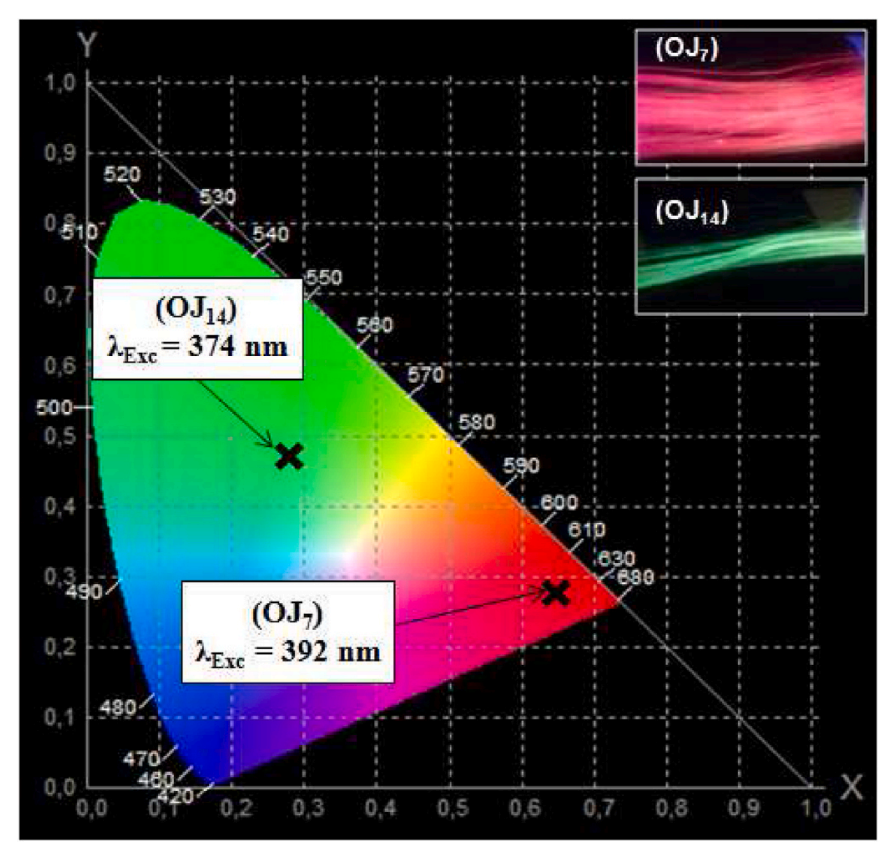

Fig. 10. CIE color coordinates of PGFs samples on CIE 1931 chromaticity diagram upon excitation at $392 \mathrm{~nm}\left(\mathrm{OJ}_{7}\right)$ and $374 \mathrm{~nm}\left(\mathrm{OJ}_{14}\right)$. 
for fibers doped with $6 \mathrm{~mol} \%$ of $\mathrm{Tb}_{2} \mathrm{O}_{3}\left(\mathrm{OJ}_{14}\right)$. The strong aggregation of $\mathrm{Eu}^{3+}$ and $\mathrm{Tb}^{3+}$ ions that occupy the interstitial sites of the glassy network increased the density with a simultaneous decrease of the molar volume, making the glassy network more compact. Thus, the Tg was also increased with increasing $\mathrm{RE}_{2} \mathrm{O}_{3}$ content. The undoped and doped fibers up to $5 \mathrm{~mol} \%$ of $\mathrm{RE}_{2} \mathrm{O}_{3}$ belong to the ultraphosphate groups rich in $\left(\mathrm{Q}^{3}\right)$. When $\mathrm{O} / \mathrm{P}=3$ for fibers doped with $6 \mathrm{~mol} \%$ of $\mathrm{RE}_{2} \mathrm{O}_{3}$, the metaphosphate groups rich in $\left(\mathrm{Q}^{2}\right)$ become dominant. This result indicates that the bond length and bond angle of P-O-P in the glassy network structure also change. However, no significant changes are observed in the FTIR spectra. The photoluminescence properties of PGFs doped with different $\mathrm{RE}_{2} \mathrm{O}_{3}$ contents were discussed in detail. The most intense emission band at $611 \mathrm{~nm}$ corresponds to the ${ }^{5} \mathrm{D}_{0} \rightarrow{ }^{7} \mathrm{~F}_{2}$ transition, leads to the red emission with a maximum absolute quantum yield equal to $20.25 \%$ observed for the $\mathrm{OJ}_{7}$ sample. The most intense emission band at $543 \mathrm{~nm}$ corresponds to the ${ }^{5} \mathrm{D}_{4} \rightarrow{ }^{7} \mathrm{~F}_{5}$ transition, leads to the green emission with a maximum absolute quantum yield equal to about $5 \%$ for the $\mathrm{OJ}_{14}$ sample. The CIE color coordinates for these two compositions were found to $(\mathrm{x}=0.648, \mathrm{y}=0.344)$ and $(\mathrm{x}=0.295, \mathrm{y}=0.477)$ lying in the red and green regions, respectively.

Given all that, we have therefore demonstrated that it is possible to synthesize PGFs with excellent luminescent properties and that the doping of $\mathrm{Eu}^{3+}$ and $\mathrm{Tb}^{3+}$ ions in the studied glass systems improves the mechanical performance and influences the structural properties of the investigated PGFs.

\section{Declaration of competing interest}

The authors declare that they have no known competing financial interests or personal relationships that could have appeared to influence the work reported in this paper.

\section{Acknowledges}

This work was supported financially by grants from the PHC-Toubkal under the project TBK/15/16, Campus France: 32506VM. We also thank the Higher School of Textiles and Clothing Industries (ESITH) and the Faculty of Sciences Ben M'scik (FSBM) for their continued support of this work.

\section{References}

[1] O. Jamal Eddine, et al., Elaboration and characterization of new phosphate glasses based on natural phosphate and red clay: influence of the chemical composition on the chemical durability, Mediterr. J. Chem. 9 (3) (2019) 222-235, https://doi.org/ 10.13171/mjc93191012614sg.

[2] A.A. Reddy, et al., Optical properties of $\mathrm{Dy}^{3+}$-doped sodium-aluminum-phosphate glasses, J. Mater. Sci. 46 (7) (2011) 2018-2023, https://doi.org/10.1007/s10853010-4851-3.

[3] V. Venkatramu, et al., Optical spectroscopy of $\mathrm{Sm}^{3+}$ ions in phosphate and fluorophosphate glasses, Opt. Mater. 29 (11) (2007) 1429-1439, https://doi.org/ 10.1016/j.optmat.2006.06.011.

[4] I.A.M. Ibrahim, et al., Electronic structure and energy level schemes of $\mathrm{RE}^{3+}$. $\mathrm{LaSi}_{3} \mathrm{~N}_{5}$ and $\mathrm{RE}^{2+}: \mathrm{LaSi}_{3} \mathrm{~N}_{5-\mathrm{x}} \mathrm{O}_{\mathrm{x}}$ phosphors $(\mathrm{RE}=\mathrm{Ce}, \mathrm{Pr}, \mathrm{ND}, \mathrm{Pm}, \mathrm{Sm}, \mathrm{Eu})$ from first principles, J. Lumin. 164 (2015) 131-137, https://doi.org/10.1016/j. jlumin.2015.03.035.

[5] L. Han, et al., A novel $\mathrm{Eu}^{3+}$-doped phosphate glass for reddish orange emission: preparation, structure and fluorescence properties, J. Lumin. 221 (2020) 117041, https://doi.org/10.1016/j.jlumin.2020.117041.

[6] R.M. Zaki, et al., Direct 3D-printing of phosphate glass by fused deposition modeling, Mater. Des. 194 (2020) 108957, https://doi.org/10.1016/j. matdes.2020.108957.

[7] L. Zhang, et al., An investigation of the optical properties of $\mathrm{Tb}^{3+}$-doped phosphate glasses for green fiber laser, Opt. Mater. 34 (7) (2012) 1202-1207, https://doi.org/ 10.1016/j.optmat.2012.01.031.

[8] S. Rada, E. Culea, FTIR spectroscopic and DFT theoretical study on structure of europium-phosphate-tellurate glasses and glass ceramics, J. Mol. Struct. 929 (1-3) (2009) 141-148, https://doi.org/10.1016/j.molstruc.2009.04.021.

[9] H. Ebendorff-Heideprie, D. Ehrt, Relationships between glass structure and spectroscopic properties of $\mathrm{Eu}^{3+}$ and $\mathrm{Tb}^{3+}$ doped glasses, Ber. Bunsenges. Physik. Chem. 100 (9) (1996) 1621-1624, https://doi.org/10.1002/bbpc.19961000955.
[10] C.R. Kesavulu, et al., Concentration effect on the spectroscopic behavior of $\mathrm{Tb}^{3+}$ ions in zinc phosphate glasses, J. Lumin. 165 (2015) 77-84, https://doi.org/ 10.1016/j.jlumin.2015.04.012.

[11] C.M. Reddy, et al., A review on optical and photoluminescence studies of $\mathrm{RE}^{3+}$ $(\mathrm{RE}=\mathrm{Sm}, \mathrm{Dy}, \mathrm{Eu}, \mathrm{Tb}$ and $\mathrm{Nd})$ ions doped LCZSFB glasses, Renew. Sustain. Energy Rev. 51 (2015) 566-584, https://doi.org/10.1016/j.rser.2015.06.025.

[12] K. Binnemans, Interpretation of europium (III) spectra, Coord. Chem. Rev. 295 (2015) 1-45, https://doi.org/10.1016/j.ccr.2015.02.015.

[13] Y. Chen, et al., Photoluminescence of Tb-doped MgAl-LDHs depending on phase transition caused by annealing, J. Rare Earths 34 (1) (2016) 36-44, https://doi. org/10.1016/S1002-0721(14)60575-5.

[14] P. Avouris, A. Campion, M.A. El-Sayed, Phonon assisted site-to-site electronic energy transfer between $\mathrm{Eu}^{3+}$ ions in an amorphous solid, Chem. Phys. Lett. 50 (1) (1977) 9-13, https://doi.org/10.1016/0009-2614(77)80669-6.

[15] E. Nakazawa, S. Shionoya, Relaxation between excited levels of $\mathrm{Tb}^{3+}$ ion due to resonance energy transfer, J. Phys. Soc. Japan 28 (5) (1970) 1260-1265, https:// doi.org/10.1143/JPSJ.28.1260.

[16] E. Takushi, T. Kushida, Anomalous spectral properties of inhomogeneously broaded transitions of $\mathrm{Eu}^{3+}$ in $\mathrm{Ca}\left(\mathrm{PO}_{3}\right)_{2}$ glass, J. Lumin. 18 (1979) 661-664, https://doi.org/10.1016/0022-2313(79)90213-8.

[17] J.R. Morgan, M.A. El-Sayed, Temporal and temperature dependence of the energy transfer process among europium (3+) in an amorphous solid, J. Phys. Chem. 85 (24) (1981) 3566-3568, https://doi.org/10.1021/j150624a008.

[18] G. Nishimura, et al., ${ }^{5} \mathrm{D}_{0}-{ }^{7} \mathrm{~F}_{0}$ transition mechanism of $\mathrm{Eu}^{3+}$ in $\mathrm{Ca}\left(\mathrm{PO}_{3}\right)_{2}$ glass, $\mathrm{Y}_{2} \mathrm{O}_{2} \mathrm{~S}$ crystal and polyvinyl alcohol, J. Lumin. 48 (1991) 473-476, https://doi.org/ 10.1016/0022-2313(91)90172-R.

[19] D. Bricis, et al., Magnetic circular dichroism of the optical absorption and optically detected ESR of X-irradiated $\mathrm{Tb}^{3+}$ doped and undoped $\mathrm{CaO} \cdot \mathrm{P}_{2} \mathrm{O}_{5}$ glasses, Solid State Commun. 81 (9) (1992) 745-748, https://doi.org/10.1016/0038-1098(92) 90781-4.

[20] O. Jamal Eddine, et al., Effect of the chemical composition on the structural and mechanical properties of phosphate glass fibers based on natural phosphate, J. Alloys Compd. 817 (2020) 152808, https://doi.org/10.1016/j. jallcom.2019.152808.

[21] O. Jamal Eddine, et al., Mechanical, structural, and chemical properties of unmodified and iron-modified phosphate glass fibers based on natural phosphate and kaolin clay, Mater. Chem. Phys. 255 (2020) 123573, https://doi.org/10.1016/ j.matchemphys.2020.123573.

[22] Carbon fibre - determination of the tensile properties of single filament specimens, international standard, ISO 11566, BS ISO 11566 (1996).

[23] M.A. Slivka, C.C. Chu, I.A. Adisaputro, Fiber-matrix interface studies on bioabsorbable composite materials for internal fixation of bone fractures. I. Raw material evaluation and measurement of fiber-matrix interfacial adhesion, J. Biomed. Mater. Res. 36 (4) (1997) 469-477, https://doi.org/10.1002/(SICI) 1097-4636(19970915)36:4<469::AID-JBM4>3.0.CO;2-C.

[24] I. Ahmed, et al., Weight loss, ion release and initial mechanical properties of a binary calcium phosphate glass fibre/PCL composite, Acta Biomater. 4 (5) (2008) 1307-1314, https://doi.org/10.1016/j.actbio.2008.03.018.

[25] R.K. Brow, et al., The effects of melt history on the failure characteristics of pristine glass fibres, Phys. Chem. Glasses 50 (1) (2009) 31-33.

[26] R.O. Omrani, et al., Structural and thermochemical study of $\mathrm{Na}_{2} \mathrm{O}-\mathrm{ZnO}-\mathrm{P}_{2} \mathrm{O}_{5}$ glasses, J. Non-Cryst. Solids 390 (2014) 5-12, https://doi.org/10.1016/j. jnoncrysol.2014.02.020.

[27] A.M.B. Silva, et al., Structural characterization of $\mathrm{TiO}_{2}-\mathrm{P}_{2} \mathrm{O}_{5}-\mathrm{CaO}$ glasses by spectroscopy, J. Eur. Ceram. Soc. 30 (6) (2010) 1253-1258, https://doi.org/ 10.1016/j.jeurceramsoc.2009.11.001.

[28] G. El-Damrawi, A.K. Hassan, A. Shahboub, ${ }^{31} \mathrm{P}$ and ${ }^{27} \mathrm{Al}$ nuclear magnetic resonance studies on silver phosphate glasses, Magn. Reson. Solids 20 (2) (2018).

[29] M. Elisa, et al., Optical and structural characterization of samarium and europiumdoped phosphate glasses, J. Non-Cryst. 369 (2013) 55-60, https://doi.org/ 10.1016/j.jnoncrysol.2013.03.024.

[30] S. Sharma, S. Jana, Luminescence properties of $\mathrm{Tb}^{3+}$ embedded zinc lead phosphate glasses, Mater. Chem. Phys. 251 (2020) 122968, https://doi.org/ 10.1016/j.matchemphys.2020.122968.

[31] S.M. Abo-Naf, et al., In vitro bioactivity evaluation, mechanical properties and microstructural characterization of $\mathrm{Na}_{2} \mathrm{O}-\mathrm{CaO}-\mathrm{B}_{2} \mathrm{O}_{3}-\mathrm{P}_{2} \mathrm{O}_{5}$ glasses, Spectrochim, Acta A Mol. Biomol. Spectrosc. 144 (2015) 88-98, https://doi.org/10.1016/j. saa.2015.02.076.

[32] W. Jastrzębski, et al., Infrared spectroscopy of different phosphates structures, Spectrochim. Acta Mol. Biomol. Spectrosc. 79 (4) (2011) 722-727, https://doi.org/ 10.1016/j.saa.2010.08.044.

[33] H.R.A. Mooghari, et al., The effects of $\mathrm{SiO}_{2}$ and $\mathrm{K}_{2} \mathrm{O}$ on glass forming ability and structure of $\mathrm{CaOTiO}_{2} \mathrm{P}_{2} \mathrm{O}_{5}$ glass system, Ceram. Int. 38 (4) (2012) 3281-3290, https://doi.org/10.1016/j.ceramint.2011.12.034.

[34] R. Reisfeld, Spectra and energy transfer of rare earths in inorganic glasses, in: Rare Earths, vol. 13, Springer, Berlin, Heidelberg, 1973, pp. 53-98, https://doi.org/ 10.1007/3-540-06125-8_2.

[35] B. Padlyak, A. Drzewiecki, Spectroscopy of the $\mathrm{CaB}_{4} \mathrm{O}_{7}$ and $\mathrm{LiCaBO}_{3}$ glasses, doped with terbium and dysprosium, J. Non-Cryst. 367 (2013) 58-69, https://doi.org/ 10.1016/j.jnoncrysol.2013.02.018.

[36] K. Linganna, C.K. Jayasankar, Optical properties of $\mathrm{Eu}^{3+}$ ions in phosphate glasses, Spectrochim. Acta Mol. Biomol. Spectrosc. 97 (2012) 788-797, https://doi.org/ 10.1016/j.saa.2012.07.031.

[37] A.K. Parchur, R.S. Ningthoujam, Behaviour of electric and magnetic dipole transitions of $\mathrm{Eu}^{3+},{ }^{5} \mathrm{D}_{0} \rightarrow{ }^{7} \mathrm{~F}_{0}$ and Eu-O charge transfer band in $\mathrm{Li}^{+}$co-doped $\mathrm{YPO}_{4}$ : $\mathrm{Eu}^{3+}$, RSC Adv. 2 (29) (2012) 10859-10868, https://doi.org/10.1039/c2ra22144f. 
[38] P. Porcher, P. Caro, Influence of J-mixing on the phenomenological interpretation of the $\mathrm{Eu}^{3+}$ ion spectroscopic properties, J. Lumin. 21 (2) (1980) 207-216, https:// doi.org/10.1016/0022-2313(80)90022-8.

[39] M. Tanaka, G. Nishimura, T. Kushida, Contribution of $J$ mixing to the ${ }^{5} D_{0}-{ }^{7} F_{0}$ transition of $\mathrm{Eu}^{3+}$ ions in several host matrices, Phys. Rev. B 49 (24) (1994) 16917 https://doi.org/10.1103/PhysRevB.49.16917.

[40] I.I. Kindrat, et al., Enhancement of the $\mathrm{Eu}^{3+}$ luminescence in $\mathrm{Li}_{2} \mathrm{~B}_{4} \mathrm{O}_{7}$ glasses codoped with Eu and Ag, J. Lumin. 204 (2018) 122-129, https://doi.org/10.1016/j. jlumin.2018.07.051.

[41] H. Wen, et al., Understanding $\mathrm{Eu}^{3+}$ emission spectra in glass, Phys. Chem. Chem. Phys. 12 (33) (2010) 9933-9937, https://doi.org/10.1039/C0CP00206B.

[42] J. Pisarska, et al., Local structure and luminescent properties of lead phosphate glasses containing rare earth ions, J. Rare Earths 29 (12) (2011) 1157-1160, https://doi.org/10.1016/S1002-0721(10)60616-3.

[43] C. Görller-Walrand, et al., Magnetic dipole transitions as standards for Judd-Ofelt parametrization in lanthanide spectra, J. Chem. Phys. 95 (5) (1991) 3099-3106, https://doi.org/10.1063/1.460867.

[44] J.E. Lowther, Spectroscopic transition probabilities of rare earth ions, J. Phys. C Solid State Phys. 7 (23) (1974) 4393, https://doi.org/10.1088/0022-3719/7/23/ 026.

[45] R. Balakrishnaiah, et al., Characterization of $\mathrm{Eu}^{3+}$-doped fluorophosphate glasses for red emission, J. Non-Cryst. 353 (13-15) (2007) 1397-1401, https://doi.org/ 10.1016/j.jnoncrysol.2006.10.063.

[46] S.S. Babu, et al., Optical absorption and photoluminescence studies of $\mathrm{Eu}^{3+}$-doped phosphate and fluorophosphate glasses, J. Lumin. 126 (1) (2007) 109-120, https://doi.org/10.1016/j.jlumin.2006.05.010.

[47] H. Ebendorff-Heidepriem, D. Ehrt, Spectroscopic properties of $\mathrm{Eu}^{3+}$ and $\mathrm{Tb}^{3+}$ ions for local structure investigations of fluoride phosphate and phosphate glasses, J. Non-Cryst. 208 (3) (1996) 205-216, https://doi.org/10.1016/S0022-3093(96) 00524-8.
[48] Y. Chen, et al., Down-conversion luminescence and optical thermometric performance of $\mathrm{Tb}^{3+} / \mathrm{Eu}^{3+}$ doped phosphate glass, J. Non-Cryst. 484 (2018) 111-117, https://doi.org/10.1016/j.jnoncrysol.2018.01.027.

[49] L.M. Marcondes, et al., High tantalum oxide content in $\mathrm{Eu}^{3+}$-doped phosphate glass and glass-ceramics for photonic applications, J. Alloys Compd. 842 (2020) 155853, https://doi.org/10.1016/j.jallcom.2020.155853.

[50] R. Priyanka, et al., Structural and spectroscopic investigations on $\mathrm{Eu}^{3+}$ ions doped boro-phosphate glasses for optical display applications, J. Lumin. 220 (2020) 116964, https://doi.org/10.1016/j.jlumin.2019.116964.

[51] P. Aryal, et al., Development of $\mathrm{Eu}^{3+}$-doped phosphate glass for red luminescent solid-state optical devices, J. Lumin. 227 (2020) 117564, https://doi.org/10.1016/ j.jlumin.2020.117564.

[52] Z. Liu, Rare Earths: New Research, Nova Science Publishers, New York, 2013.

[53] P.A. Azeem, et al., Spectroscopic investigations on $\mathrm{Tb}^{3+}$ doped lead fluoroborate glasses, Opt Commun. 285 (18) (2012) 3787-3791, https://doi.org/10.1016/j. optcom.2012.05.034.

[54] M. Venkateswarlu, B.H. Rudramadevi, Luminescence analysis of $\mathrm{Eu}^{3+}$ and $\mathrm{Tb}^{3+}$ ions doped borate zinc magnesium glasses, Int. J. Sci. Res. 4 (4) (2015) 3179-3184.

[55] V.X. Quang, et al., Role of modifier ion radius in luminescence enhancement from ${ }^{5} \mathrm{D}_{4}$ level of $\mathrm{Tb}^{3+}$ ion doped alkali-alumino-telluroborate glasses, J. Lumin. 221 (2020) 117039, https://doi.org/10.1016/j.jlumin.2020.117039.

[56] A.U. Trápala-Ramírez, et al., Calcium-zinc phosphate glasses activated with $\mathrm{Tb}^{3+}$ / $\mathrm{Eu}^{3+}$ for laser and white LED applications, J. Lumin. 215 (2019) 116621, https:// doi.org/10.1016/j.jlumin.2019.116621.

[57] H.I. Francisco-Rodriguez, et al., Lithium-aluminum-zinc phosphate glasses activated with $\mathrm{Tb}^{3+}$ and $\mathrm{Tb}^{3+} / \mathrm{Eu}^{3+}$ for green laser medium, reddish-orange and white phosphor applications, Opt. Mater. 79 (2018) 358-365, https://doi.org/ 10.1016/j.optmat.2018.04.004.

[58] R. Martínez-Martínez, et al., Cold white light generation from hafnium oxide films activated with $\mathrm{Ce}^{3+}, \mathrm{Tb}^{3+}$, and $\mathrm{Mn}^{2+}$ ions, J. Mater. Res. 25 (3) (2010) 484-490, https://doi.org/10.1557/JMR.2010.0065. 